\title{
Mass spectrometry reveals distinct proteomic profiles in high- and low-quality stallion spermatozoa
}

\author{
Róisín A Griffin ${ }^{1}$, Aleona Swegen ${ }^{1,2}$, Mark Baker ${ }^{1}$, Robert John Aitken ${ }^{1}$, David A Skerrett-Byrne, \\ Antonio Silva Rodriguez ${ }^{3}$, Francisco E Martín-Cano ${ }^{4}$, Brett Nixon ${ }^{1,5}$, Fernando J Peña ${ }^{4}$, \\ Maryse Delehedde ${ }^{6}$, Nicolas Sergeant ${ }^{6,7}$ and Zamira Gibb ${ }^{1}$ \\ ${ }^{1}$ Priority Research Centre for Reproductive Science, University of Newcastle, New South Wales, Australia, ${ }^{2}$ Nuffield \\ Department of Women's and Reproductive Health, University of Oxford, Oxford, UK, ${ }^{3}$ Facility of Innovation and \\ Analysis in Animal Source Foodstuffs, University of Extremadura, Cáceres, Spain, ${ }^{4}$ Laboratory of Equine \\ Reproduction and Equine Spermatology, Veterinary Teaching Hospital, University of Extremadura, Cáceres, Spain, \\ ${ }^{5}$ Pregnancy and Reproduction Program, Hunter Medical Research Institute, New South Wales, Australia, ${ }^{6}$ SPQI - \\ 4BioDx-Breeding Section, Lille, France and 'INSERM UMRS1172, CHU-Lille, LilNCog Research Center, University of \\ Lille, Lille, France
}

Correspondence should be addressed to R A Griffin; Email: roisin.griffin@uon.edu.au

\begin{abstract}
The horse breeding industry relies upon optimal stallion fertility. Conventional sperm assessments provide limited information regarding ejaculate quality and are not individually predictive of fertilizing potential. The aim of this study was to harness mass spectrometry to compare the proteomic profiles of high- and low-quality stallion spermatozoa, with the ultimate goal of identifying fertility biomarker candidates. Extended stallion semen $(n=12)$ was fractionated using Percoll density gradients to isolate low-quality and high-quality sperm populations. Motility and morphological assessments were carried out, and proteomic analyses was conducted using UHPLC-MS/MS. High-quality spermatozoa recorded higher total $(95.2 \pm 0.52 \%$ vs $70.6 \pm 4.20 \% ; P \leq 0.001)$ and progressive motilities $(43.4 \pm 3.42 \%$ vs $27.3 \pm 4.32 \% ; P \leq \mathbf{0 . 0 5})$, and a higher proportion of morphologically normal cells $(50.2 \pm$ $4.34 \%$ vs $38.8 \pm 2.72 \% ; P \leq \mathbf{0 . 0 5}$ ). In total, 1069 proteins were quantified by UHPLC-MS/MS, of which 22 proteins were significantly more abundant in the high-quality sperm population $(P \leq 0.05)$. A-kinase anchor protein 4 (AKAP4) and Hexokinase 1 (HK1) were considered possible biomarker candidates and their differential expression was confirmed by immunoblot. Protein expression was significantly correlated with total (AKAP4 $R^{2}=0.38, P \leq 0.01$; HK1 $R^{2}=0.46, P \leq 0.001$ ) and progressive motilities $\left(\right.$ AKAP4 $R^{2}=0.51, P \leq 0.001 ;$ HK1 $R^{2}=0.55, P \leq 0.01$ ), percentage rapid (AKAP4 $R^{2}=0.29, P \leq 0.05 ; H K 1 R^{2}=0.58, P \leq 0.001$ ), straight-line velocity (HK1 $\left.R^{2}=0.50, P \leq 0.01\right)$ and straightness (HK1 $\left.R^{2}=0.40, P \leq 0.01\right)$. Furthermore, AKAP4 was highly susceptible to adduction by 4-hydroxynonenal (4HNE), which resulted in a global reduction in the phosphorylation profiles following capacitation. In conclusion, the proteomic profiles of high- and low-quality stallion spermatozoa differ substantially, and proteins such as AKAP4 and HK1 could serve as biomarkers of ejaculate quality.

Reproduction (2020) 160 695-707
\end{abstract}

\section{Introduction}

The selection of stallions for breeding focuses on pedigree and racetrack success rather than heritable reproductive traits, therefore, stallions experience lower per cycle conception (PCC) rates compared to other livestock species (Colenbrander et al. 1993, Parlevliet \& Colenbrander 1999, Morris \& Allen 2002, Nath et al. 2010). The Thoroughbred stud book prohibits the use of assisted reproductive technologies, while also imposing an official foal birthdate of January 1st in the northern hemisphere, and August 1st in the southern hemisphere; effectively reducing the commercial breeding season to a 4-month period. Such measures mean that breeders experience significant pressure to achieve pregnancies as close to the start of the breeding season as possible, as larger and more mature horses will reach greater success both at yearling sales and on the racetrack (Pagan et al. 2005, Takahashi 2015).

The result of a given breeding cannot be ascertained until approximately 14 days post-breeding or insemination. Conventional sperm assessments, such as sperm concentration, viability, motility, and morphological assessment, although valuable, provide only limited information regarding ejaculate quality, and are not entirely predictive of the fertilizing potential (Parlevliet \& Colenbrander 1999, Colenbrander et al. 2003, Petrunkina et al. 2007). Moreover, our knowledge 
of the underlying molecular mechanisms leading to the formation of defective spermatozoa - and therefore periods of subfertility - is lacking compared to certain other species (Park et al. 2012, Intasqui et al. 2013, Kwon et al. 2015a,b, Cui et al. 2016, Netherton et al. 2017).

Unravelling the events that govern a conception success or failure, and understanding the molecular cascades that regulate fertility, requires a systems biology approach utilizing high throughput omics technologies. The advent of increasingly sophisticated proteomic technologies has enabled many detailed investigations, not only into the composition of mammalian spermatozoa (Baker et al. 2008, Somashekar et al. 2015, Swegen et al. 2015, Sergeant et al. 2016, Martín-Cano et al. 2020), but also into the identification of numerous proteomic fertility biomarker candidates in mice (Baker et al. 2005), men (de Mateo et al. 2007, Netherton et al. 2017), bulls (Park et al. 2012, Somashekar et al. 2017) and boars (Kwon et al. 2015a,b). To our knowledge, only one study has utilized omics technologies in identifying such biomarkers in stallion ejaculates (Novak et al. 2010), and reported that sperm protein expression accounted for only $10 \%$ of fertility variability. This study analyzed the full complement of cells within ejaculates, with no selection criteria to remove the dead or indeed lowquality cells; unlikely to reach the site of fertilization. Consequently, it remains unclear how a high-quality and high functioning spermatozoon, capable of fertilization, differs in composition from a low-quality cell.

Density gradient centrifugation is currently the most effective method of isolating sperm populations of differing quality within an ejaculate. Sperm populations isolated using this technique are associated with greater yields of motile, viable, morphologically normal spermatozoa, with improved fertilizing capacity, and higher pregnancy success rates (Guerin et al. 1989, Punjabi et al. 1990, Shalika et al. 1995, Sharma \& Agarwal 1996, Carbone et al. 1997, Morrell et al. 2011, Karamahmutoglu et al. 2014). This technique also enables the direct comparison of sperm parameters and molecular attributes, facilitating the identification of biomarkers of fertility (Park et al. 2012, Cui et al. 2016, Netherton et al. 2017).

We hypothesize that by harnessing mass spectrometry technologies to compare the proteomic profile of highquality and low-quality spermatozoa, separated using discontinuous density gradient centrifugation, we will identify robust biomarkers of ejaculate quality.

\section{Materials and methods}

\section{Reagents}

Unless specified, research-grade chemical reagents were obtained from Sigma-Aldrich. A modified Biggers, Whitten and Whittingham (BWW) medium (Biggers et al. 1971) containing $95 \mathrm{mM} \mathrm{NaCl}, 4.7 \mathrm{mM} \mathrm{KCl}, 1.7 \mathrm{mM} \mathrm{CaCl}{ }_{2} 2 \mathrm{H}_{2} \mathrm{O}$, $1.2 \mathrm{mM} \mathrm{KH} \mathrm{PO}_{4}, 1.2 \mathrm{mM} \mathrm{MgSO}{ }_{4} \cdot 7 \mathrm{H}_{2} \mathrm{O}, 25 \mathrm{mM} \mathrm{NaHCO}{ }_{3}$,
$5.6 \mathrm{mM}$ D-glucose, $275 \mathrm{mM}$ sodium pyruvate, $3.7 \mu \mathrm{L} / \mathrm{mL}$ $60 \%$ sodium lactate syrup, $50 \mathrm{U} / \mathrm{mL}$ penicillin, $50 \mathrm{mg} / \mathrm{mL}$ streptomycin, $20 \mathrm{mM}$ HEPES (GE Healthcare) and $0.1 \%$ $(\mathrm{w} / \mathrm{v})$ polyvinyl alcohol, with an osmolarity of $310 \mathrm{mOsm} / \mathrm{kg}$, was utilized throughout this study. The following antibodies were purchased to characterize proteins of interest: mouse monoclonal anti-AKAP4 (clone 7E10) from 4BioDx (Lille, France), mouse monoclonal anti-Hexokinase1 (Abcam), monoclonal anti-Tubulin (Sigma-Aldrich), rabbit polyclonal anti-4HNE (HNE11-S; Alpha Diagnostic International, San Antonio, TX, USA) rabbit polyclonal anti-GAPDH antibodies (G9545; Sigma-Aldrich), monoclonal anti-phosphotyrosine (P5872; Sigma-Aldrich). Percoll, nitrocellulose membranes and enhanced chemiluminescence (ECL) detection reagents were purchased from GE Healthcare, and Tris was purchased from Astral Scientific (Taren Point, NSW, Australia). Chloroform and methanol were purchased from Fronine (Riverstone, NSW, Australia) at the highest purity available. Ultrapure water was from Fluka (Castle Hill, NSW Australia). 3-[(3-cholamidopropyl)dimethylammonio]1-propanesulfonate (CHAPS) was obtained from Research Organics (Cleveland, OH, USA). Dynabeads Protein G and 3,3'-dithiobis[sulfosuccinimidyl propionate] (DTSSP) were purchased from Thermo Fisher Scientific. Mini-PROTEAN TGX Precast (4-20\%) Protein Gels were purchased from Bio-Rad Laboratories. Paraformaldehyde was obtained from ProSciTech (Thuringowa, Qld, Australia).

\section{Preparation of Stallion Spermatozoa}

Institutional and New South Wales State Government ethical approval was secured for the use of animal material in this study. Semen samples were collected on three occasions from four normozoospermic Shetland and Miniature crossbred pony stallions (between six and nine years of age) of proven fertility, housed on institution-approved premises. Stallions had access to native pasture $24 \mathrm{~h}$ a day and were provided with supplementary feed consisting of grass and lucerne hay once daily.

Semen was collected using a pony-sized Missouri or Colorado artificial vagina (Minitube Australia, Ballarat, VIC, Australia) with an inline semen filter. Ejaculates were immediately diluted (2:1, extender:semen) using EquiPlus extender (Minitube Australia) and transported to the laboratory $(\sim 1 \mathrm{~h})$. On arrival at the laboratory, the extended semen was fractionated using 40\%/80\% Percoll gradients, as previously described by Mitchell et al. (2011). This technique is frequently utilized to isolate spermatozoa of differing quality - in terms of motility, morphology and DNA integrity - within an ejaculate (Aitken et al. 2013, Xavier et al. 2018). Moreover, Percoll gradients were recently used to successfully identify proteins of differential expression between high- and poorquality spermatozoa in men (Netherton et al. 2017). Following centrifugation (500 g, $25 \mathrm{~min}$ ), purified spermatozoa were recovered from the $40 \% / 80 \%$ Percoll interface (low-quality sperm), and from the $80 \%$ pellet (high-quality sperm). Samples were washed in BWW medium (500 g, $20 \mathrm{~min}$ ) and resuspended at a concentration of $40 \times 10^{6}$ cells $/ \mathrm{mL}$ in BWW, for use in all assays. 


\section{Motility analysis}

Sperm motility was objectively determined using computerassisted sperm analysis (CASA; IVOS, Hamilton Thorne, Danvers, MA), with the following settings: negative phasecontrast optics, recording rate of 60 frames/s, minimum contrast of 70, minimum cell size of 4 pixels, low-size gate of 0.17 , high-size gate of 2.9, low-intensity gate of 0.6 , high-intensity gate of 1.74 nonmotile head size of 10 pixels, nonmotile head intensity of 135, progressive smoothed path velocity (VAP) threshold of $50 \mu \mathrm{m} / \mathrm{s}$, slow (static) cell VAP threshold of $20 \mu \mathrm{m} / \mathrm{s}$, slow (static) cell straight-line velocity (VSL) threshold of $0 \mu \mathrm{m} / \mathrm{s}$, and threshold straightness (STR) of $75 \%$. Cells exhibiting a VAP of $\geq 50 \mu \mathrm{m} / \mathrm{s}$ and a STR of $\geq 75 \%$ were considered progressive. Cells with a VAP greater than that of the mean VAP of progressive cells were considered 'rapid'. A minimum of 200 spermatozoa, in a minimum of five fields were assessed using $20 \mu \mathrm{m}$ Leja standard count slides (Gytech, Hawthorne East, VIC, Australia) and a stage temperature of $37^{\circ} \mathrm{C}$.

\section{Morphology}

Approximately $4 \times 10^{6}$ spermatozoa were fixed in $2 \%$ paraformaldehyde for $10 \mathrm{~min}$ at $4^{\circ} \mathrm{C}$, washed in PBS, and stored in $0.1 \mathrm{M}$ glycine in PBS. Morphology was assessed using phase-contrast microscopy (Olympus CX40) at 1000× magnification under oil immersion. A total of 100 cells were classified per sample as either being normal or having abnormalities of the head, midpiece, tail, or proximal or distal cytoplasmic droplets, as previously described (Sieme 2009).

\section{Measurement of sperm dimensions}

Approximately $4 \times 10^{6}$ spermatozoa were fixed in $2 \%$ paraformaldehyde, as described previously. Cells were visualized using phase-contrast microscopy (Zeiss Axio Imager A1) at 1000× magnification under oil immersion and the following measurements were recorded on 100 cells per sample; length of head, width of head, length of midpiece and length of tail using Olympus cellSense Standard (v2.3) software.

\section{Cell lysis}

High-quality $(n=12)$ and low-quality spermatozoa $(n=12)$ isolated from the ejaculates of four stallions, collected on three occasions, were snap frozen in aliquots containing $40 \times 10^{6}$ cells, and stored at $-80^{\circ} \mathrm{C}$ until all samples could be assessed collectively. Approximately $80 \mu \mathrm{L}$ of lysis buffer consisting of $1 \%(\mathrm{w} / \mathrm{v}) \mathrm{C} 7 \mathrm{BzO}$ [3-(4-Heptyl) phenyl-(3-hydroxypropyl) dimethylammoniopropanesulfonate], $7 \mathrm{M}$ urea, $2 \mathrm{M}$ thiourea, and $40 \mathrm{mM}$ Tris $(\mathrm{pH} 10.4)$ was added to a pellet of $40 \times 10^{6}$ spermatozoa in Eppendorf tubes, for $1 \mathrm{~h}$ at $4{ }^{\circ} \mathrm{C}$ with constant rotation. Samples were centrifuged $(18,000 \mathrm{~g}, 15 \mathrm{~min})$, and supernatants were recovered and transferred to fresh tubes. Protein quantification was performed using a 2D quant kit (GE Healthcare) following the manufacturer's protocol.

\section{Protein precipitation}

Lysate was collected and reduced using $10 \mathrm{mM}$ 1,4-dithiolthreitol (DTT) for $1 \mathrm{~h}$ at room temperature (RT) and then alkylated with $20 \mathrm{mM}$ iodoacetamide (IAA) for one $\mathrm{h}$ at $\mathrm{RT}$, in the dark. Approximately $100 \mu \mathrm{g}$ of protein per sample were precipitated using the methanol/chloroform protocol, as described previously (Wessel \& Flügge 1984). Briefly, lysates were adjusted to $400 \mu \mathrm{L}$ with ultrapure water. Methanol and chloroform were then added to lysates at a ratio of 2:2:1 (lysate: $\mathrm{MeOH}: \mathrm{CHCl}_{3}$ ), inverted and centrifuged briefly $(17,000 \mathrm{~g}, 1 \mathrm{~min})$. The upper aqueous phase was removed (leaving the interfaced, protein precipitate layer intact), and $300 \mu \mathrm{L}$ methanol was added. Lysates were gently inverted and centrifuged $(17,000 \mathrm{~g})$ for $15 \mathrm{~min}$. Supernatants were discarded and lysates were air-dried for $15 \mathrm{~min}$ at RT.

\section{In-solution trypsin digestion}

Protein pellets were solubilized in $200 \mu \mathrm{L}$ of $5 \mathrm{M}$ urea and mixed with $100 \mu \mathrm{L}$ of $25 \mathrm{mM}$ ammonium bicarbonate buffer $(\mathrm{pH}$ 8.5). Proteins were reduced by adding $30 \mu \mathrm{L}$ of $10 \mathrm{mM}$ DTT $\left(20 \mathrm{~min}, 56^{\circ} \mathrm{C}\right)$ and alkylated by adding $30 \mu \mathrm{l}$ of $20 \mathrm{mM}$ IAA (30 min, RT) in the dark. Digestion was performed by adding $1 \mu \mathrm{L}$ of proteomics grade trypsin $(1 \mu \mathrm{g} / \mu \mathrm{L}$ in trypsin 1 $\mathrm{mM} \mathrm{HCl})$ and samples were incubated overnight $\left(37^{\circ} \mathrm{C}\right)$. The reaction was stopped using $10 \mu \mathrm{L}$ of $0.1 \%$ formic acid, and filtering samples through $0.2 \mu \mathrm{m}$ (hydrophilic PTFE) into a 2 $\mathrm{mL}$ dark glass vial. Finally, samples were dried using a nitrogen current at $35^{\circ} \mathrm{C}$ and resuspended in $20 \mu \mathrm{L}$ of $\mathrm{H}_{2} \mathrm{O}$ /acetonitrile/ formic acid buffer (94.9:5:0.1).

\section{UHPLC-MS/MS analysis}

The separation and analysis of the samples were performed using the ultra high performance liquid chromatography tandem mass spectrometry (UHPLC-MS/MS); consisting of an Agilent 1290 Infinity II Series HPLC (Agilent Technologies), equipped with an automated multi-sampler module and a high speed binary pump, and coupled to an Agilent 6550 Q-TOF Mass Spectrometer (Agilent Technologies), using an Agilent Jet Stream Dual electrospray (AJS-Dual ESI) interface. The control of the UHPLC-MS and Q-TOF were made using MassHunter Workstation Data Acquisition software (Agilent Technologies, Rev. B.06.01). Samples were injected onto an Agilent AdvanceBio Peptide Mapping HPLC column $(2.7 \mu \mathrm{m}$, $150 \times 2.1 \mathrm{~mm}$, Agilent technologies), at $55^{\circ} \mathrm{C}$, at a flow rate of $0.4 \mathrm{~mL} / \mathrm{min}$. The gradient program began with $2 \%$ of buffer $\mathrm{B}$ $\left(\mathrm{H}_{2} \mathrm{O}\right.$ /acetonitrile/formic acid buffer, 10:89.9:0.1) in isocratic mode (5 min), increasing linearly to $45 \%$ (40 min), followed by $95 \%$ (15 min), remaining constant for five min. Buffer $\mathrm{A}$ : $\mathrm{H}_{2} \mathrm{O}$ /acetonitrile/formic acid buffer, 89.9:10:0.1. The mass spectrometer was operated in the positive mode. The nebuliser gas pressure was set to $35 \mathrm{PSI}$, drying gas flow was set to 10 $\mathrm{L} / \mathrm{min}$ at a temperature of $250^{\circ} \mathrm{C}$, and the sheath gas flow was set to $12 \mathrm{~L} / \mathrm{min}$ at a temperature of $300^{\circ} \mathrm{C}$. The capillary spray, fragmentor and octopole RF Vpp voltages were 3500, 340 and $750 \mathrm{~V}$, respectively. Profile data were acquired for both MS and MS/MS scans in extended dynamic range mode. MS and MS/ 
MS mass range was $50-1700 \mathrm{~m} / \mathrm{z}$, and scan rates were eight spectra/sec for MS, and three spectra/s for MS/MS. Auto MS/ MS mode was used with precursor selection by abundance and a maximum of 20 precursors selected per cycle. A ramped collision energy was used with a slope of 3.6 and an offset of -4.8. The same ion was rejected after two consecutive scans.

\section{Proteomic data processing and analysis}

Data processing was performed using Spectrum Mill MS Proteomics Workbench (rev B.04.01, Agilent Technologies). Briefly, raw data were extracted under default conditions as follows: non fixed or variable modifications were selected; $[\mathrm{MH}]+50-10,000 \mathrm{~m} / \mathrm{z}$; maximum precursor charge +5; retention time and $\mathrm{m} / \mathrm{z}$ tolerance $\pm 60 \mathrm{~s}$; minimum signalto-noise MS (S/N) 25; finding ${ }^{12} \mathrm{C}$ signals. The MS/MS was searched against the UniProt horse database (downloaded September 2019) and performed with the following criteria; no fixed modifications, carbamidomethylated cysteines (variable modification); tryptic digestion with a maximum of five missed cleavages; ESI-Q-TOF instrument; minimum matched peak intensity $50 \%$; maximum ambiguous precursor charge +5 ; monoisotopic masses; peptide precursor mass tolerance 20 ppm; product ion mass tolerance 50 ppm; and calculation of reversed database scores. Validation of peptide and protein data was performed using auto thresholds with a false discovery rate of $1.2 \%$ and summarized using the validations; score $>5$ and $60 \%$ SPI (Scored Peak Intensity: the percentage of the extracted spectrum that is explained by the database search result).

Exported protein lists were imported to Perseus (version 1.6.10.43; Tyanova et al. 2016), and z-scoring normalization was performed on transformed data, followed by Student's t-tests. From this data, volcano plots were created between high- and low-quality populations harvested from each individual stallion, where the $x$-axis is the $\log _{2}$ fold change and the $y$-axis is the $-\log _{10} P$ value score (Nixon et al. 2019b). Using the refined protein list (Supplementary Table 1, see section on supplementary materials given at the end of this article), accessions were mapped to UniProt to collate information on level of protein evidence and associated Gene Ontology classifications of biological processes, molecular function and cell localization. In cases of obsolete or deleted protein entries (109 proteins), a Basic Local Alignment Search Tool (BLAST) search was carried out to identify putative genes, based on a minimum 50\% shared identity (Supplementary Table 1). The initial protein list was further refined, based on the inclusion of proteins with a quantitative value in at least two technical replicates of one stallion, resulting in the identification of 499 proteins (denoted by fold change and $P$-values; Supplementary Table 1).

\section{SDS-PAGE and immunoblotting}

Candidate proteins that demonstrated a statistically significant fold-change between sperm fractions, and a spectral count $>100$, were identified. These proteins were cross-checked against a literature search of studies identifying fertility biomarker proteins in various species. A-kinase anchor protein
4 (AKAP4) and Hexokinase 1 (HK1) were repeated implicated (Intasqui et al. 2013, Frapsauce et al. 2014, Cui et al. 2016, Blommaert et al. 2019) and were therefore chosen for validation by immunoblotting. All cells were boiled $\left(100^{\circ} \mathrm{C}, 5\right.$ $\mathrm{min})$ in sodium dodecylsulphate (SDS) extraction buffer $(0.375$ $M$ Tris $\mathrm{pH} 6.8,2 \%$, w/v SDS, $10 \%$, w/v sucrose, protease inhibitor cocktail) to extract protein. Samples were centrifuged $\left(17,000 \mathrm{~g}, 15 \mathrm{~min}, 4^{\circ} \mathrm{C}\right)$ and soluble protein remaining in the supernatant was quantified using a DC protein assay kit (Bio-Rad). A total of $10 \mu \mathrm{g}$ of protein from each sample was boiled $\left(5 \mathrm{~min}, 100^{\circ} \mathrm{C}\right.$ ) in SDS-PAGE (PAGE) sample buffer (2\%, v/v mercaptoethanol, $2 \%, \mathrm{w} / \mathrm{v}$ SDS, and $10 \%, \mathrm{w} / \mathrm{v}$ sucrose in $0.375 \mathrm{M}$ Tris, $\mathrm{pH}$ 6.8, with bromophenol blue). Protein was resolved by SDS-PAGE $(150 \mathrm{~V}, 1 \mathrm{~h})$, transferred to nitrocellulose membranes (350 mA, 1 h), and blocked (1 h, RT) in 5\% skimmed milk, or 3\% BSA in Tris-buffered saline (TBS; $100 \mathrm{mM}$ Tris- $\mathrm{HCl}, \mathrm{pH} 7.6$, and $150 \mathrm{mM} \mathrm{NaCl}$ ) supplemented with $0.1 \%$ Tween-20 (TBST). Primary antibodies for AKAP4 $(1: 1000)$ and 4HNE (1:500) were diluted in 1\% skim milk/ TBST, while those for HK1 (1:1000), Tubulin (1:3000) and GAPDH (1:4000) were diluted in 1\% BSA/TBST. Membranes were incubated in primary antibody overnight $\left(4^{\circ} \mathrm{C}\right)$ under rotation and probed ( $1 \mathrm{~h}, \mathrm{RT})$ with appropriate horseradish peroxidase-conjugated secondary antibodies diluted in $1 \%$ skim milk/TBST or BSA/TBST (anti-rabbit 1:2500; anti-mouse 1:2000). Following washing (three times for $5 \mathrm{~min}$ in TBST), cross-reactive proteins were visualized using an enhanced chemiluminescence (ECL) kit, according to the manufacturer's instructions, and exposed to a digital camera LAS-3000 system (GE Healthcare). Semi-quantification was achieved using ImageJ software (NIH). Sperm SDS lysate blots were stripped and re-probed with anti-Tubulin or anti-GAPDH antibody as a loading control.

\section{Co-immunoprecipitation}

Co-immunoprecipitation (IP) was utilized to assess the covalent modification of AKAP4 by 4 HNE in high and low-quality sperm populations. Spermatozoa were lysed in IP lysis buffer $(10 \mathrm{mM}$ CHAPS, $10 \mathrm{mM}$ HEPES, $137 \mathrm{mM} \mathrm{NaCl}$ and $10 \%$ glycerol) on constant rotation $\left(2 \mathrm{~h}, 4^{\circ} \mathrm{C}\right)$. Lysates were recovered following centrifugation $\left(13,800 \mathrm{~g}, 20 \mathrm{~min}, 4^{\circ} \mathrm{C}\right)$ and $100 \mu \mathrm{L}$ was added to $50 \mu \mathrm{L}$ aliquots of washed Dynabeads and incubated under rotation to preclear $\left(1 \mathrm{~h}, 4^{\circ} \mathrm{C}\right)$. Anti-AKAP4 antibody $(10 \mu \mathrm{g}$ in $200 \mu \mathrm{L}$ of PBS) was conjugated to fresh aliquots of washed Dynabeads (supernatant removed) by incubation under rotation $\left(2 \mathrm{~h}, 4^{\circ} \mathrm{C}\right)$. Cross-linking was performed by adding 3,3'-dithiobis[sulfosuccinimidyl propionate] (DTSSP) at a final concentration of $2 \mathrm{mM}$ (30 min, RT), after which $2 \mathrm{mM}$ Tris was added (15 min, RT) to quench the reaction. Dynabeads were then washed three times in $200 \mu \mathrm{L}$ of lysis buffer and supernatants were retained. Immunoprecipitation was performed by adding $100 \mu \mathrm{L}$ of lysates to AKAP4 antibodybound beads and incubating on constant rotation overnight $\left(4^{\circ} \mathrm{C}\right)$. Supernatants were transferred to fresh tubes and washed three times in $200 \mu \mathrm{L}$ of PBS. Beads were resuspended in 100 $\mu \mathrm{L}$ of PBS and transferred to fresh tubes to avoid co-elution of proteins bound to the tube. Antibody-antigen-bound beads, precleared beads, $10 \mu \mathrm{L}$ of fresh protein $\mathrm{G}$ beads (bead-only 
control), $5 \mu \mathrm{L}$ anti-AKAP4 (antibody-only control) and $5 \mu \mathrm{L}$ of the final PBS wash of the antibody bound beads (negative control) were boiled in SDS loading buffer (containing 8\% $\beta$-mercaptoethanol) for $5 \mathrm{~min}$ to elute proteins. The eluted proteins were then loaded onto a 4-20\% Tris-Glycine gel, resolved by SDS-PAGE $(150 \mathrm{~V}, 1 \mathrm{~h})$ transferred to nitrocellulose membranes (350 mA, $1 \mathrm{~h}$ ) and blocked as detailed previously. The blots of eluted sperm proteins were probed with antiAKAP4, then stripped and re-probed with anti-4HNE antibody to assess $4 \mathrm{HNE}$ adduction.

\section{HNE treatment and capacitation}

4HNE was used to assess the effects of aldehyde exposure on tyrosine phosphorylation. Spermatozoa recovered from $40 \% / 80 \%$ Percoll interface, and from the $80 \%$ pellet were incubated $\left(30 \mathrm{~min}, 37^{\circ} \mathrm{C}\right)$ with $4 \operatorname{HNE}(0,50$ or $100 \mu \mathrm{M})$, washed in BWW (500 g, $3 \mathrm{~min}$ ) and resuspended in $500 \mu \mathrm{L}$ of BWW capacitation medium $(0.5 \mathrm{mM}$ methyl- $\beta$-cyclodextrin, $3.0 \mathrm{mM}$ pentoxifylline, $5 \mathrm{mM}$ dibutyryl cyclic AMP, $3 \mathrm{mg}$ BSA in $10 \mathrm{ml}$ BWW; Bromfield et al. 2014) or normal BWW medium in flat-bottom tubes. All samples were incubated under an atmosphere of $5 \% \mathrm{CO}_{2}$ and $95 \%$ air for $4 \mathrm{~h}\left(37^{\circ} \mathrm{C}\right)$. Throughout the incubation period, sperm suspensions were gently inverted at $30 \mathrm{~min}$ intervals to prevent settling of the cells. Samples were gently centrifuged (500 g, $3 \mathrm{~min}$ ), supernatant was removed, and the resulting pellet was frozen $\left(-80^{\circ} \mathrm{C}\right)$. Immunoblotting was performed as detailed previously. Membranes were blocked (3\% BSA/TBST) and then probed with anti-phosphotyrosine antibody ( $\alpha$-PT66) diluted in $1 \%$ BSA/TBST $(1: 2000)$ under constant rotation overnight $\left(4^{\circ} \mathrm{C}\right)$. Membranes were washed, probed with antimouse HRP secondary antibody (1:2000 in 1\% BSA/TBST) and visualized.

\section{Statistical analyses}

Normality checks were conducted on all data using ShapiroWilk test in SPSS version 25 software (IBM Corp.) and where data was not normally distributed, appropriate data transformations were performed depending on the degree and direction of skewness. T-tests and Pearson correlations were performed using SPSS v 25 software (IBM Corp.).

\section{Results}

\section{Assessment and characterization of high- and low-quality sperm fractions}

Purified poor-quality spermatozoa were recovered from the $40 \% / 80 \%$-Percoll interface and highquality spermatozoa were recovered from the $80 \%$ pellet. Significant differences in motility and cell morphology were evident between high- and lowquality spermatozoa. An average of $43.4 \%$ ( $\pm 3.42 \%)$ of the high-quality sperm fraction demonstrated forward, progressive motility, in comparison with only $27.3 \%$ $( \pm 4.32 \%)$ of the low-quality sperm fraction $(P \leq 0.05$; Fig. 1A). Specific morphological assessments of both
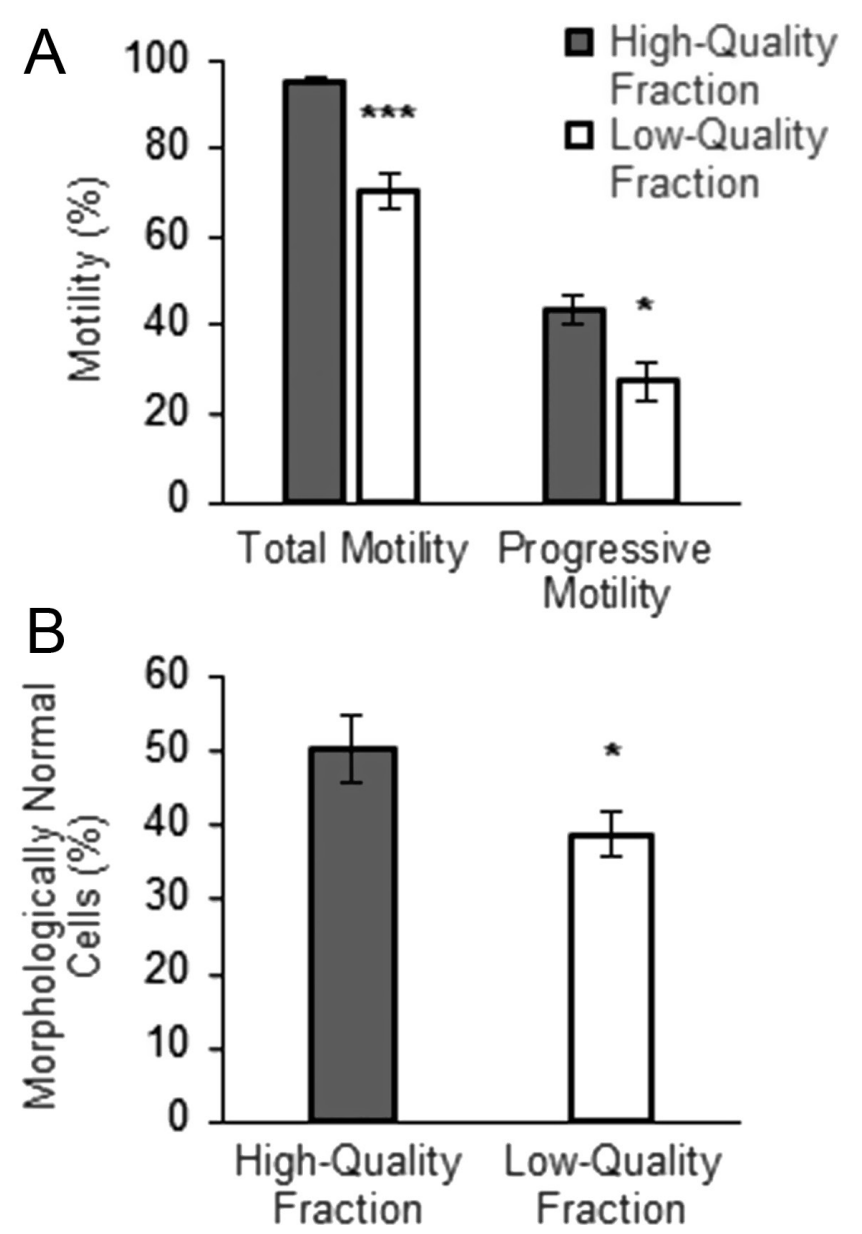

Figure 1 Total and progressive motility (A), and the percentage of morphologically normal cells (B) in high-quality (closed bar) and low-quality (open bar) sperm fractions $(n=12)$. Data correspond to mean values \pm S.E.M.. ${ }^{*} P \leq 0.05,{ }^{* * *} P \leq 0.001$.

populations revealed $50.2 \%( \pm 4.34 \%)$ of the highquality sperm fraction were classed as morphologically normal, in comparison to $38.8 \%( \pm 2.72 \%)$ of the lowquality sperm fraction $(P \leq 0.05$; Fig. 1B). Morphological abnormalities detected between populations are presented in Table 1.

Table 1 Proportion of morphological abnormalities present in high- (80\%-Percoll fraction) and low-quality (40\%-Percoll fraction) sperm populations.

\begin{tabular}{lccc}
\hline Classification & $\begin{array}{c}\text { High quality } \\
\text { sperm } \\
\text { fraction }(\%)\end{array}$ & $\begin{array}{c}\text { Low quality } \\
\text { sperm } \\
\text { fraction }(\%)\end{array}$ & $\boldsymbol{P}$-value \\
\hline Morphologically normal & $50.2 \pm 4.34$ & $38.8 \pm 2.72$ & $\leq 0.05$ \\
Head abnormality & $17.6 \pm 2.59$ & $24.2 \pm 2.97$ & $\mathrm{~N} / \mathrm{S}$ \\
Mid-piece abnormality & $21.6 \pm 3.22$ & $21.5 \pm 1.96$ & $\mathrm{~N} / \mathrm{S}$ \\
Tail abnormality & $7.2 \pm 2.27$ & $9.5 \pm 2.41$ & $\mathrm{~N} / \mathrm{S}$ \\
Proximal cytoplasmicdroplet & $1.9 \pm 0.78$ & $4.2 \pm 1.05$ & $\mathrm{~N} / \mathrm{S}$ \\
Distal cytoplasmic droplet & $1.6 \pm 0.66$ & $1.9 \pm 0.59$ & $\mathrm{~N} / \mathrm{S}$ \\
\hline
\end{tabular}


Table 2 List of identified proteins with significantly higher abundance in high-quality Percoll-derived spermatozoa, compared to low-quality Percoll-derived spermatozoa.

\begin{tabular}{|c|c|c|c|c|}
\hline $\begin{array}{l}\text { Uniprot } \\
\text { accession no. }\end{array}$ & Protein & Gene & $P$-value & Fold change \\
\hline F6Y1A5 & Phospholipase A2 receptor 1 & PLA2R1 & 0.001 & 104.35 \\
\hline F7CZM1 & Cytochrome c oxidase subunit $5 \mathrm{~A}$ & COX5A & 0.001 & 13.50 \\
\hline Q6H321 & Kallikrein-1E2 & KLK1E2 & 0.002 & 9.69 \\
\hline K9K2H8 & Mitochondrial 3-ketoacyl-CoA thiolase-like protein & $A C A A 2$ & 0.002 & 16.50 \\
\hline F6TCZ6 & GRB2 associated regulator of MAPK1 subtype 2 & GAREM2 & 0.002 & 195.25 \\
\hline F7DN04 & RPTOR independent companion of MTOR complex 2 & RICTOR & 0.003 & 82.37 \\
\hline F6ZWQ8 & Parkin coregulated & PACRG & 0.005 & 8.32 \\
\hline F7ANR3 & Proteasome subunit alpha type & PSMA3 & 0.014 & 57.75 \\
\hline F6RBE2 & Glyceraldehyde-3-phosphate dehydrogenase & GAPDHS & 0.014 & 1.06 \\
\hline F7BUS7 & TSC22 domain family member 4 & TSC22D4 & 0.016 & 205.33 \\
\hline F6ZKT4 & Adenylate kinase 8 & $A K 8$ & 0.016 & 38.32 \\
\hline F6Y0B1 & A-kinase anchoring protein 4 & AKAP4 & 0.016 & 1.18 \\
\hline F6ZMI7 & Lysozyme A & $L Y Z L 4$ & 0.017 & 4.43 \\
\hline F7AAD0 & Sperm acrosome associated 3 & SPACA3 & 0.021 & 2.91 \\
\hline F6ZD33 & Septin 8 & SEPTIN8 & 0.026 & 37.69 \\
\hline B3IVM0 & Pyruvate kinase & $P K M$ & 0.028 & 1.71 \\
\hline F6WSG0 & Oxoglutarate dehydrogenase & $O G D H$ & 0.028 & 29.52 \\
\hline F7BXF3 & Histone $\mathrm{H} 2 \mathrm{~A}$ & $H 2 A X$ & 0.030 & 11.55 \\
\hline F6WY50 & NADH:ubiquinone oxidoreductase subunit S4 & NDUFS4 & 0.032 & 92.22 \\
\hline F7E1S0 & Rho GTPase activating protein $11 \mathrm{~A}$ & ARHGAP11A & 0.049 & 428.08 \\
\hline F7BA85 & Hexokinase 1 & $H K 1$ & 0.050 & 1.53 \\
\hline K9KEM4 & ADP/ATP translocase 2-like protein & SLC25A5 & 0.051 & 3.39 \\
\hline
\end{tabular}

\section{Proteomic characterization of high- and low-quality sperm fractions}

Data obtained from UHPLC-MS/MS identified 1069 proteins (Supplementary Table 1), and the abundance of 22 of these proteins were significantly higher in the high-quality Percoll-fractionated spermatozoa than in the low-quality spermatozoa (Table 2). Based on our analysis using the UniProt Equine database, of the 1069 proteins we identified, only $1 \%$ have reported evidence at protein level (Fig. 2A). Of the remaining; 66 have evidence at transcript level only; 309 are inferred from homology; while 578 are predicted, with no evidence at protein, transcript, or homology levels. A total of 109 protein entries were obsolete or deleted, and were replaced with putative genes following a BLAST search (Supplementary Table 1).

To determine the key biological processes and molecular functions involved in the development of lowquality spermatozoa, protein accessions were mapped to UniProt. Classification according to biological process (Fig. 2B) revealed the dominant categories to be those associated with positive regulation (365 proteins), negative regulation (246 proteins), and the response to stimuli (187 proteins). When the category of positive regulation was analyzed further, the most represented processes included the regulation of transcription and translation (35 proteins); the regulation of protein activity (including expression, localization and post-translational modifications - 64 proteins); and the regulation of cellular processes (including growth, differentiation and apoptosis - 33 proteins). The category of negative regulation mapped to similar primary categories representing 33 (transcription and translation); 32 (regulation of protein activity); and 52 proteins (regulation of cellular processes), while the principal categories comprising 'response to stimuli' were; response to stress (including heat and oxidative stress - 32 proteins); pathogenic response (27 proteins); protein response (namely the folding of proteins -12 proteins); and finally, response to DNA damage (8 proteins). Volcano plots were constructed to highlight the inter-individual variability in protein abundance between high- and low-quality cell populations collected from stallions 1-4 (Fig. 2C, D, E and F, respectively).

\section{Immunoblotting validation}

Two candidate proteins were chosen for validation by immunoblotting using the criteria of a statistically significant fold-change between sperm fractions, and a spectral count $>100$. These included Hexokinase 1 (HK1) and A-kinase anchor protein 4 (AKAP4). In both cases, these proteins were identified as significantly more abundant in the high-quality sperm fraction when compared to the low-quality fraction $(P \leq 0.05)$. An immunoblot using the anti-HK1 antibody demonstrated a major band of $\sim 100 \mathrm{kDa}$ (Fig. 3A), which could be normalized to the loading control (Fig. 3B); only two representative blots are shown. Band density quantification of all high-quality $(n=12)$ and lowquality $(n=12)$ samples analyzed, confirmed our MS analysis findings (Fig. 3C). To highlight the functional significance of these results, the relationship between HK1 band density and sperm motility $(n=12)$ was 

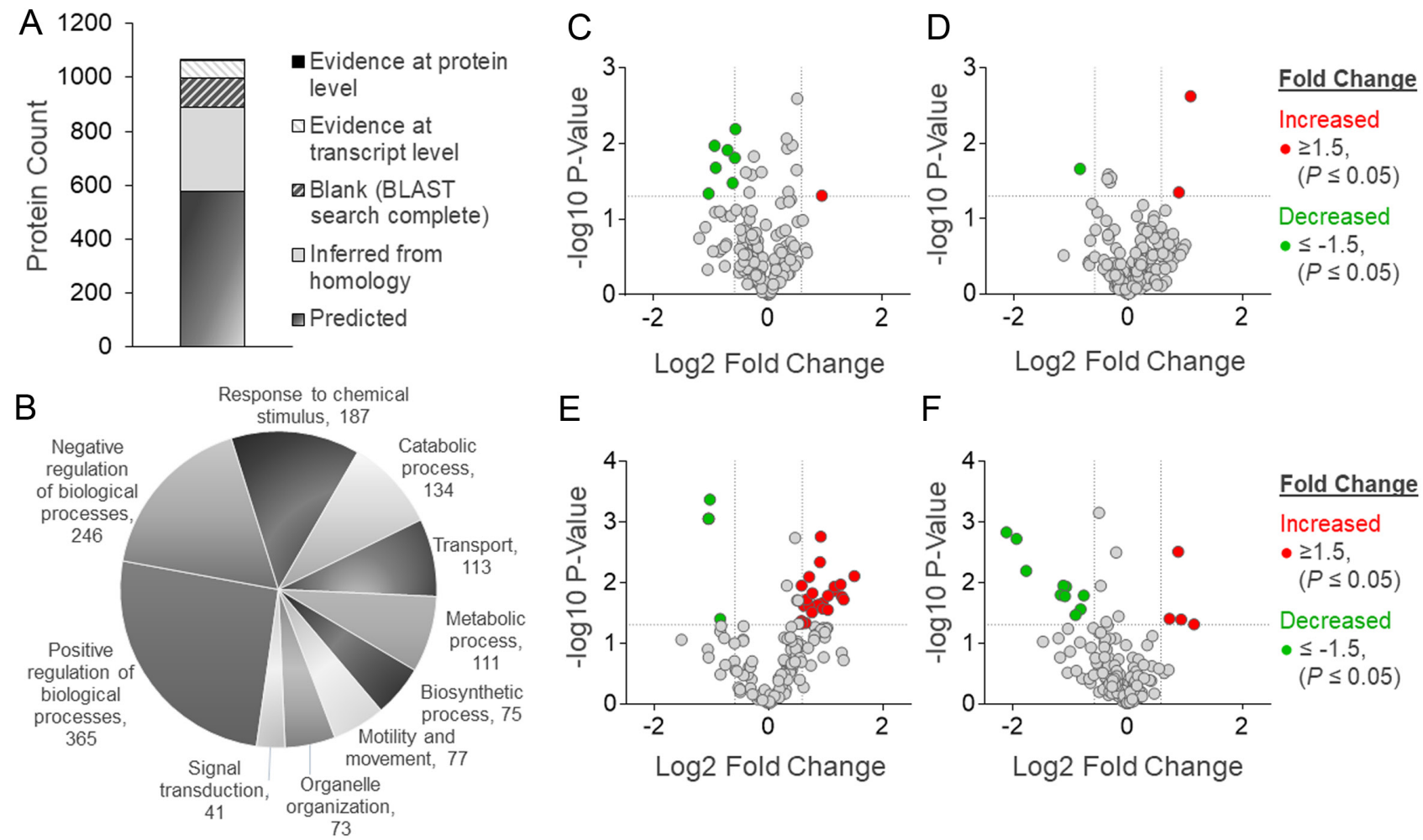

Figure 2 Compositional analysis of proteomic data, and inter-stallion variability in protein expression. (A) Classification of protein existence, according to UniProt. (B) Gene Ontology annotation of biological processes. The ten most highly represented categories (highest number of assigned proteins) are shown. (C, D, E and F) Volcano plots corresponding to stallions 1-4 highlight inter-stallion variability in protein expression; $x$-axis ( $\log _{2}$ fold change) and $y$-axis $\left(-\log _{10} P\right.$ value; cut off $\geq 1.3$ ).
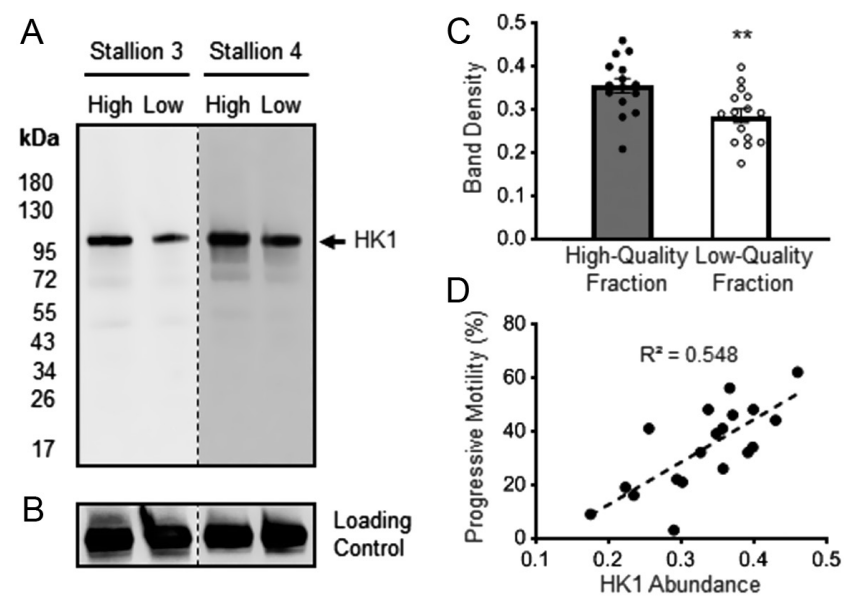

Figure 3 Assessment of HK1 expression in sperm populations. (A) Cells were lysed in an SDS-based extraction buffer, resolved by SDS-PAGE and prepared for immunoblotting with anti-HK1 antibodies $(n=12)$. (B) Blots were subsequently stripped and probed with anti-Tubulin antibodies as a loading control. Representative blots of lysates from high-quality ('high') and low-quality ('low') sperm fractions are shown. (C) Band densitometry analysis of HK1 $(100 \mathrm{kDa})$; mean values ( \pm S.E.M.) are presented relative to the corresponding Tubulin control. (D) Correlation between progressive motility and HK1 abundance. ${ }^{* *} P \leq 0.01$. assessed. Positive correlations existed between the HK1 abundance in high- and low-quality spermatozoa and total motility $\left(R^{2}=0.46, P \leq 0.001\right)$, progressive motility $\left(R^{2}=0.55, P \leq 0.001 ;\right.$ Fig. $\left.3 \mathrm{D}\right)$, rapid motility $\left(R^{2}=0.58\right.$, $P \leq 0.001), \operatorname{VSL}\left(R^{2}=0.50, P \leq 0.01\right), \mathrm{STR}\left(R^{2}=0.40\right.$, $P \leq 0.01)$ and $\operatorname{LIN}\left(R^{2}=0.32, P \leq 0.05\right)$.

An immunoblot using the anti-AKAP4 antibody demonstrated major bands of $\sim 82$ and $\sim 110 \mathrm{kDa}$ corresponding with AKAP4 and its precursor molecule proAKAP4, respectively (Fig. 4A), which could be normalized to the loading control (Fig. 4B); only three representative blots are shown. Plotting the $\sim 82 \mathrm{kDa}$ AKAP4 band densities of all high-quality $(n=12)$ and low-quality $(n=12)$ samples assessed, confirmed the findings of our MS analysis ( $P \leq 0.05$; Fig. 4C). ProAKAP4 abundance was also significantly higher in the high-quality compared to the low-quality sperm fraction $(P \leq 0.05$, $n=12$ ). Strong, positive correlations existed between AKAP4 expression $(n=12)$ and total motility $\left(R^{2}=0.38\right.$, $P \leq 0.01)$, progressive motility $\left(R^{2}=0.49, P \leq 0.001\right.$; Fig. $4 \mathrm{D})$ and rapid motility $\left(R^{2}=0.29, P \leq 0.05\right)$.

\section{Sperm dimensions}

To confirm that the underexpression of AKAP4 and HK1 in low-quality sperm fractions was not the result 

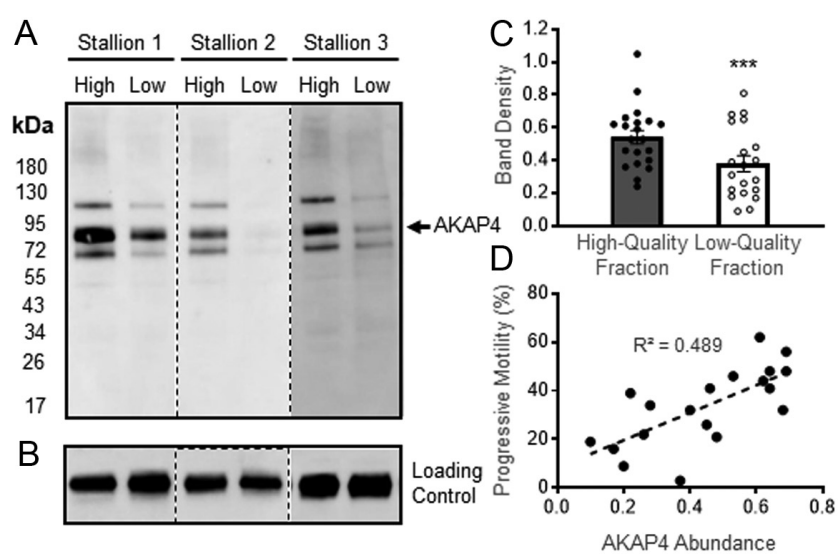

Figure 4 Assessment of AKAP4 expression in sperm populations. (A) Cells were lysed in an SDS-based extraction buffer, resolved by SDS-PAGE and prepared for immunoblotting with anti-AKAP4 antibodies $(n=12)$. (B) Blots were subsequently stripped and probed with anti-Tubulin antibodies as a loading control. Representative blots of lysates from high-quality ('high') and low-quality ('low') sperm fractions are shown. (C) Band densitometry analysis of AKAP4 (82 kDa); mean values ( \pm S.E.M.) are presented relative to the corresponding Tubulin control. (D) Correlation between progressive motility and AKAP4 abundance. ${ }^{* * *} P \leq 0.001$.

of sperm fragmentation or differences in cell size, we measured the mid-piece length, tail length, head length and head width of 100 cells from each sample. No significant differences were present between the head length $(7.0 \pm 0.04 \mu \mathrm{m}$ vs $7.0 \pm 0.04 \mu \mathrm{m})$, head width $(3.7 \pm 0.04 \mu \mathrm{m}$ vs $3.7 \pm 0.03 \mu \mathrm{m})$, mid-piece length $(10.4 \pm 0.06 \mu \mathrm{m}$ vs $10.6 \pm 0.06 \mu \mathrm{m})$, tail length $(48.0$ $\pm 0.25 \mu \mathrm{m}$ vs $47.9 \pm 0.19 \mu \mathrm{m}$ ), or mid-piece:tail length ratio (ratio $4.6 \pm 0.03$ vs $4.6 \pm 0.03$ ) of spermatozoa isolated from high- and low-quality sperm fractions.

\section{Co-immunoprecipitation}

To explore the conservation and extent of AKAP4 aldehyde adduction in stallion sperm fractions, co-immunoprecipitation was performed, whereby sperm lysates were precipitated with anti-AKAP4 antibody, and the eluates were subsequently examined for the presence of AKAP4 and 4HNE. As illustrated in Fig. 5A, this technique effectively isolated AKAP4, and following subsequent stripping and re-probing of these blots, predominant bands of $4 \mathrm{HNE}$ were detected at an equivalent molecular weight to AKAP4 (82 kDa), thus confirming AKAP4 as a target for 4HNE adduction in stallion spermatozoa (Fig. 5B). Moreover, densitometry analysis confirmed 4HNE adduction was significantly higher in high-quality spermatozoa (which possess a higher quantity of the AKAP4 substrate; Fig. 5A and C) than low-quality spermatozoa ( $P \leq 0.05$; Fig. 5C). The inclusion of immunobead-only and antibody-only controls, together with preclear bead eluates, and beadwashes prior to elution, verified the specificity of each immunoprecipitation.
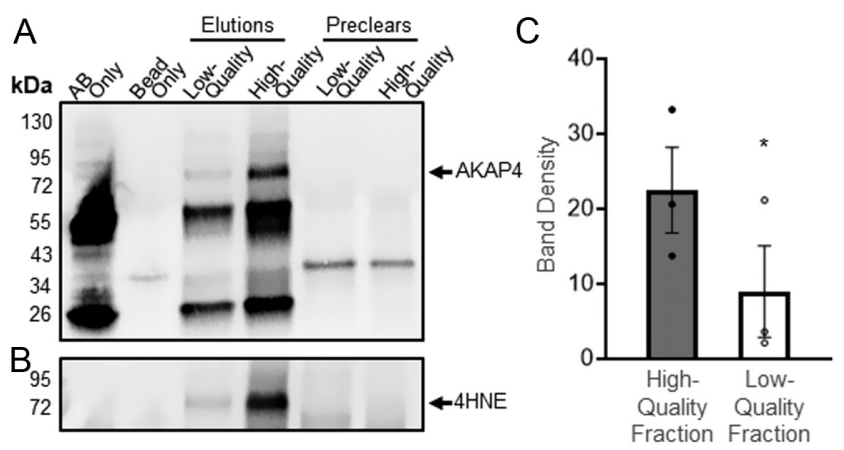

Figure 5 Analysis of $4 \mathrm{HNE}$ adduction to AKAP4. (A) Confirmation of AKAP4/4HNE interaction in both high-quality and low-quality sperm populations and was sought using immunoprecipitation, whereby AKAP4 was used to pull down interacting partners. The captured sperm proteins were eluted from protein $G$ Dynabeads and resolved on SDS-PAGE gels alongside an antibody-only control (AB only), a bead-only control (bead only), sperm lysates (high-quality and low-quality fraction elutions) and precleared controls (high-quality and low-quality fraction preclears). (B) Re-probing these blots with anti-4HNE revealed heavy adduction of $4 \mathrm{HNE}$ to AKAP4 at $82 \mathrm{kDa}$ in both elutions. (C) Band densitometry analysis of $4 \mathrm{HNE}$ bound to AKAP4 (82 kDa); mean values ( \pm S.E.M.) are presented relative to the corresponding AKAP4 band density. $* P \leq 0.05$

\section{HNE adduction and stallion sperm capacitation}

Given that AKAP4 was heavily adducted by 4 HNE in high-quality stallion spermatozoa, we extended our analysis to assess the consequences of $4 \mathrm{HNE}$ adduction on the ability of these cells to undergo capacitation as assessed by phosphotyrosine labelling; a key correlate of the capacitation process. Immunoblotting revealed that $4 \mathrm{HNE}$ treatment (both 50 and $100 \mu \mathrm{M}$ concentrations) caused a global reduction in the tyrosine phosphorylation profile (Fig. 6A, C and D), particularly seen in bands resolving at 64-70 kDa, with significant under-expression or absence in cells which had been subject to $4 \mathrm{HNE}$ insult prior to capacitation (Fig. 6E).

\section{Discussion}

This is the first study to identify differentially accumulated proteins between the high- and low-quality sperm fractions of stallion ejaculates. A total of 1069 proteins were identified using UHPLC-MS/MS (Supplementary Table 1), of which 22 exhibited significantly higher abundance in the high-quality sperm fraction (Table 2). The identification of these proteins will lead to many future investigations regarding sperm function, quality, composition and overall stallion fertility. Furthermore, we have provided experimental evidence for 1063 stallion sperm proteins which were otherwise predicted, inferred or shown at transcript level only (Fig. 2A).

The differential expression of two of these proteins - Hexokinase 1 (HK1) and A-kinase anchor protein 4 (AKAP4) - was confirmed by immunoblotting analysis. Hexokinases are a family of enzymes functioning in 

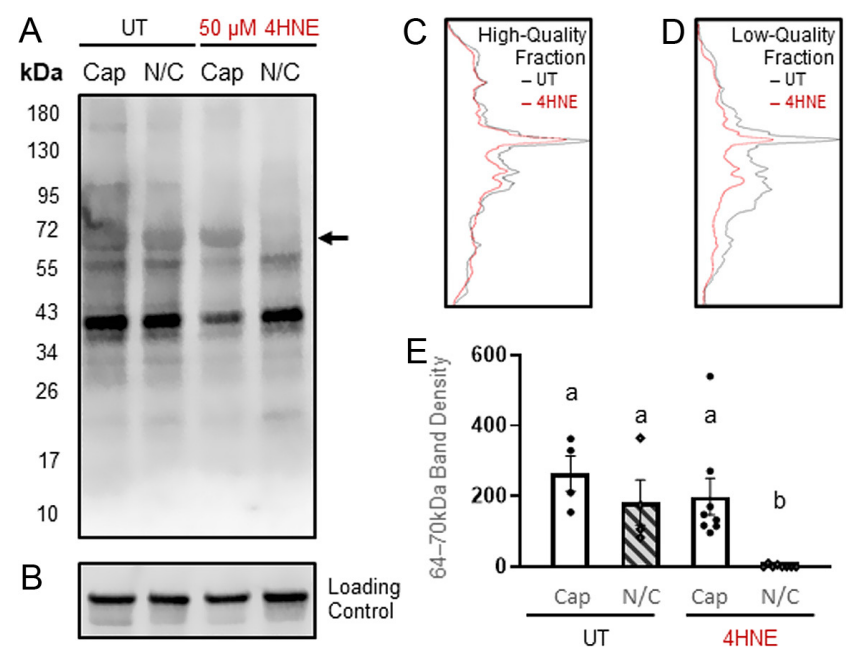

Figure $64 \mathrm{HNE}$ treatment attenuates capacitation-associated tyrosine phosphorylation. High-quality and low-quality sperm populations were either exposed to $4 \mathrm{HNE}$ (50 or $100 \mu \mathrm{M}$ ) or untreated ('UT'), and incubated for $1 \mathrm{~h}$ at $37^{\circ} \mathrm{C}$. Spermatozoa were induced to capacitate ('Cap') or held in a non-capacitated state ('N/C') using standard protocols. (A and B) Spermatozoa were subsequently prepared for immunoblotting with anti-phosphotyrosine antibodies and re-probed with a loading control (representative blots shown). (C and D) A densitometric trace of representative immunoblots is included to highlight changes in phospho-labelling in untreated (UT; black trace) and $50 \mu \mathrm{M} 4 \mathrm{HNE}$ treated (4HNE; red trace) spermatozoa isolated from the high- and low-quality Percoll fractions. (E) Densitometry analysis of bands $64-70 \mathrm{kDa}$; mean values ( \pm S.E.M.) are presented relative to the corresponding loading control. Mean values without a common superscript differ significantly $(P \leq 0.001)$.

the first step of glucose metabolism, by catalysing the phosphorylation of glucose to glucose-6-phosphate (G6P; Wilson 2003). HK1, the most ubiquitous of the major hexokinase isoforms, is localized to the sperm midpiece and fibrous sheath, via the porin binding domain in its hydrophobic N-terminal (Polakis \& Wilson 1985, Wilson 2003, Sun et al. 2008). HK1 has previously been implicated as a marker of fertility in men (Intasqui et al. 2013, Cui et al. 2016, Fanny et al. 2018). Cui et al. (2016) reported a significantly higher abundance of HK1 in the high-quality sperm fraction, while Intasqui et al. (2013) reported higher HK1 abundance in spermatozoa with low levels of DNA damage. In the present study, the functional significance of HK1 was reinforced by the existence of a strong, positive relationship between HK1 expression and numerous motility parameters (Fig. 3D); a result that is not surprising considering the involvement of HK1 in energy metabolism (Wilson 2003).

In spermatozoa, AKAP4 is the most abundant member of the AKAP family - a conserved dynasty of diverse scaffolding proteins - which conduct pivotal roles in fibrous sheath formation, motility, capacitation and acrosome reaction, while orchestrating the integration of cAMP and various components of signal-transduction pathways (Colledge \& Scott 1999, Moss et al. 1999, Miki et al. 2002, Brown et al. 2003, Welch et al. 2010, Luconi et al. 2011, Langeberg \& Scott 2015, Rahamim Ben-Navi et al. 2016). Localized to the principal piece of the sperm flagellum, AKAP4 accounts for almost $50 \%$ of all fibrous sheath proteins (Carrera et al. 1994, Eddy et al. 2003, Krisfalusi et al. 2006). Considering the vital roles played by AKAP, it is not surprising that its underexpression has been repeatedly implicated in infertility in men (Xu et al. 2012, Frapsauce et al. 2014) bulls (Peddinti et al. 2008, Legare et al. 2017, Singh et al. 2019) and stallions (Blommaert et al. 2019). AKAP4 is synthesized from its precursor molecule proAKAP4, (Delehedde et al. 2019, Sergeant et al. 2019), which we identified at $\sim 110 \mathrm{kDa}$ (Fig. 4A). Recently, proAKAP4 expression has been strongly correlated with total and progressive motility in stallion spermatozoa (Blommaert et al. 2018, Blommaert et al. 2019), and has, therefore, become the focus of many investigations into its use as a biomarker of ejaculate quality in dogs, bulls, boars, stallions and men (Delehedde et al. 2018, 2019, Le Couazer et al. 2019, Ruelle et al. 2019, Sergeant et al. 2019). Differences in AKAP4 abundance in the present study most likely stem from defective proAKAP4 expression. Herein, we confirmed previous findings that AKAP4 is significantly more abundant in high-quality spermatozoa isolated using density gradient centrifugation (Cui et al. 2016), and that AKAP4 expression is significantly correlated with motility parameters (Fanny et al. 2018, Blommaert et al. 2019) (Fig. 4D).

Although protein abundance was greater in all highquality sperm fractions analyzed, we found that AKAP4 was a statistically stronger marker of sperm quality in samples collected from half of the stallions, while HK1 was statistically stronger in samples collected from the other half. Indeed, Fig. 2C, D and F highlight the extent of protein expression variability between stallions. These results indicate first; that the formation of low-quality sperm fractions in an ejaculate is not governed by one singular protein, and second; that some stallions may be more adversely affected by the under-expression of distinct proteins, giving rise to the formation of lowquality spermatozoa. It may be possible that molecular interactions can overcome particular defects that arise during protein synthesis. For instance, sperm tail proteins SPAG5 and ODF1 interact via leucine zipper motifs; deletion of which obliterates this interaction (Shao et al. 2001). However, SPAG5 contains an alternate leucine zipper motif that does not interact with ODF1, suggesting its ability to interact with other proteins to maintain functional capacity (Shao et al. 2001). In the case of results presented here, some stallions may possess the necessary machinery to surmount interruptions to the synthesis of a particular protein (e.g. AKAP4, but not HK1), thereby explaining the differences in statistical strength of sperm quality markers between individuals. It appears that the use of a single biomarker to predict stallion fertility may not be the most appropriate strategy. Rather, there is likely benefit in developing a robust, 
multi-biomarker diagnostic platform, which accounts for inter-individual variability, and can simultaneously quantify a suite of biomarkers, increasing the predictive power of the assay.

The cytotoxic aldehyde 4-hydroxynonenal (4HNE) is a major end-product of lipid peroxidation, formed following the oxidation of polyunsaturated fatty acids (PUFA). Once produced, 4HNE covalently binds to the sidechains of amino acids, perturbing protein function (Esterbauer et al. 1991, Doorn \& Petersen 2002, Dalleau et al. 2013) and leading to pronounced dysfunction in both male (Baker et al. 2015, Bromfield et al. 2015b, Moazamian et al. 2015) and female germlines (Lord et al. 2015, Mihalas et al. 2017). ProAKAP4 and AKAP4 have been identified as primary targets of $4 \mathrm{HNE}$ adduction in both round spermatids and mature spermatozoa (Baker et al. 2015, Nixon et al. 2019a). After treating cells with exogenous 4HNE, Baker et al. (2015) identified a number of AKAP4 peptides containing 4HNE carbonyl adducts, and reported a significant 11-fold increase in the number of modified residues present. These modified residues exist in close proximity to numerous important phosphorylation sites (Nixon et al. 2019a). In the present study, immunoprecipitation revealed significant adduction of AKAP4 by 4HNE (Fig. 5), while treatment with exogenous $4 \mathrm{HNE}$ resulted in a global reduction in phosphorylation profile (Fig. 6). Equine spermatozoa have a unique matrix of antioxidants that neutralize free radicals, but this ability is lost over time when antioxidant defences become overwhelmed (Gibb et al. 2016). The greater reduction in phosphorylation profile exhibited by the low-quality sperm fraction (Fig. 6C and D) may result from an inferior defense system exposing cells to detrimental oxidative attack more rapidly than higher quality cells.

Stallion spermatozoa are distinct in that their high dependence on oxidative phosphorylation means that markers of oxidative stress are positively correlated with sperm function (Gibb et al. 2014). As AKAPs are highly vulnerable to 4HNE adduction (Nixon et al. 2019a), in functional, high-quality cells, this may explain why equine sperm prove difficult to capacitate, and consequently why IVF in this species has rarely been achieved.

Immunoblotting revealed a significant loss or degradation of bands resolving at $64-70 \mathrm{kDa}$ in noncapacitated, 4HNE treated samples (Fig. 6A and E). We suspect that these bands may represent a multiprotein complex involving heat shock-related $70 \mathrm{kDa}$ protein 2 (HSPA2), arylsulfatase A (ARSA; $68 \mathrm{kDa}$ ) and the testis-associated serine proteases testisin (PRSS21; 70 $\mathrm{kDa}$ ), among others. HSPA2 has been implicated as one of the initial targets of 4HNE-mediated modification (Bromfield et al. 2015b). HSPA2 functions in preventing the aggregation of misfolded proteins (Mayer \& Bukau 2005), and therefore protection of other vital cell proteins from oxidative attack. In equine spermatozoa, adduction of 4HNE to HSPA2 disrupts the HSPA2/ ARSA/SPAM1 complex that participates in sperm-egg recognition; ultimately rendering the sperm incapable of fertilization (Bromfield et al. 2015a). ARSA - a protein vital for zona pellucida adhesion and binding (Carmona et al. 2002, Redgrove et al. 2012a,b, Bromfield et al. 2015a) - has been identified resolving at $68 \mathrm{kDa}$ in capacitated boar sperm (Jiménez et al. 2006), and shares $90 \%$ sequence identity with equine ARSA. Testisin was recently characterized in stallion spermatozoa, and holds a functional relationship with HSPA2 (Swegen et al. 2019). Localized to both the sperm tail and the inner acrosomal membrane, testisin has been implicated as an integral member of the zona pellucida-binding complex (Netzel-Arnett et al. 2009, Swegen et al. 2019). The significant degradation of bands resolving at 64-70 $\mathrm{kDa}$ in the present study confirms previous findings that, even in low concentrations, cytotoxic aldehydes can have a significant effect on overall mammalian cell function (Bromfield et al. 2015a,b, Hall et al. 2017).

Driven by the limitations imposed by the Thoroughbred breeding and racing industries, there is increasing pressure to produce foals close to the commencement of the breeding season. Decreases in stallion fertility generate a host of economic and welfare implications concerning both mares and stallions. Increasing our knowledge of the molecular factors that govern stallion fertility, will pave the way toward identifying putative biomarkers of sperm function. Such breakthroughs would facilitate the close monitoring of the molecular changes - predictive of future fertility outcomes - via the regular collection of post-coital dismount semen samples. Sperm populations collected from dismount samples are highly representative of whole ejaculate quality (Gibb et al. 2014). The results of such analyses will enable the timely adjustment of management strategies, well before mares begin to return negative pregnancy diagnoses.

In conclusion, we identified several proteins whose expression is distinctly different between high- and lowquality stallion spermatozoa isolated from the same ejaculate, and established their functional significance by highlighting significant correlations present between protein abundance and motility. The research findings presented herein will go a long way toward the development of a robust, multi-biomarker diagnostic platform, capable of accurately predicting sperm function - the development of which could potentially improve overall horse welfare and the economic conditions surrounding Thoroughbred ownership. Further research is needed to investigate the usefulness of AKAP4 and HK1 for predicting times of high and low fertility in the field.

\section{Supplementary materials}

This is linked to the online version of the paper at https://doi. org/10.1530/REP-20-0284. 


\section{Declaration of interest}

Maryse Delehedde and Nicolas Sergeant are both co-founders of the SPQI company (Lille, France) that commercialise the AKAP4 antibody used in this study. Robert Aitken is on the editorial board of Reproduction. Robert Aitken was not involved in the review or editorial process for this paper, on which he is listed as an author.

\section{Funding}

This work was supported by Ministerio de Ciencia-FEDER (Madrid, AGL2017-83149-R), Junta de Extremadura-FEDER (IB16030 and GR18008) and the Australian Research Council in conjunction with the following partner organisations under Linkage Grant LP160100824: the Hunter Valley Equine Research Council, Memphasys Ltd, Texas A\&M University, the University of Sydney, EquiBreed NZ Ltd, CellOxess, Harness Racing Australia and Scone Equine Hospital.

\section{Author contribution statement}

Z G, A S and R J A initiated and designed the study with input from R A G, M B, B N, M D and N S. R A G performed experiments and data collection. UHPLC-MS/MS was facilitated by F J P and performed by A S R and F E M-C. Data analysis was performed by $R A G$ with assistance from $M B$ and D A S-B; facilitated by B N. R A G drafted the original manuscript which was sent to all authors for correction.

\section{Acknowledgements}

The authors gratefully acknowledge the technical assistance of Shenae L Cafe and Stephanie Waugh.

\section{References}

Aitken RJ, Smith TB, Lord T, Kuczera L, Koppers AJ, Naumovski N, Connaughton H, Baker MA \& De luliis GN 2013 On methods for the detection of reactive oxygen species generation by human spermatozoa: analysis of the cellular responses to catechol oestrogen, lipid aldehyde, menadione and arachidonic acid. Andrology 1 192-205. (https://doi. org/10.1111/j.2047-2927.2012.00056.x)

Baker MA, Witherdin R, Hetherington L, Cunningham-Smith K \& Aitken RJ 2005 Identification of post-translational modifications that occur during sperm maturation using difference in two-dimensional gel electrophoresis. Proteomics 5 1003-1012. (https://doi.org/10.1002/pmic.200401100)

Baker MA, Hetherington L, Reeves GM \& Aitken RJ 2008 The mouse sperm proteome characterized via IPG strip prefractionation and LC-MS/ MS identification. Proteomics 8 1720-1730. (https://doi.org/10.1002/ pmic.200701020)

Baker MA, Weinberg A, Hetherington L, Villaverde AI, Velkov T, Baell J \& Gordon CP 2015 Defining the mechanisms by which the reactive oxygen species by-product, 4-hydroxynonenal, affects human sperm cell function. Biology of Reproduction 92 108. (https://doi.org/10.1095/ biolreprod.114.126680)

Biggers J, Whitten W \& Whittingham D 1971 The culture of mouse embryos in vitro. In Methods in Mammalian Embryology. Ed JC Daniel. San Francisco: Freeman.

Blommaert D, Sergeant N, Delehedde M, Franck T, Lejeune JP \& Serteyn D 2018 Significant correlation between the proAKAP4 concentration and the total and progressive motility in stallion sperm after thawing.
Journal of Equine Veterinary Science 66 43. (https://doi.org/10.1016/j. jevs.2018.05.019)

Blommaert D, Sergeant N, Delehedde M, Jouy N, Mitchell V, Franck T, Donnay I, Lejeune JP \& Serteyn D 2019 Expression, localization, and concentration of A-kinase anchor protein 4 (AKAP4) and its precursor (proAKAP4) in equine semen: promising marker correlated to the total and progressive motility in thawed spermatozoa. Theriogenology 131 52-60. (https://doi.org/10.1016/j.theriogenology.2019.03.011)

Bromfield EG, Aitken RJ, Gibb Z, Lambourne SR \& Nixon B 2014 Capacitation in the presence of methyl- $\beta$-cyclodextrin results in enhanced zona pellucida-binding ability of stallion spermatozoa. Reproduction 147 153-166. (https://doi.org/10.1530/REP-13-0393)

Bromfield E, Aitken RJ \& Nixon B 2015a Novel characterization of the HSPA2-stabilizing protein BAG6 in human spermatozoa. Molecular Human Reproduction 21 755-769. (https://doi.org/10.1093/molehr/ gav041)

Bromfield EG, Aitken RJ, Anderson AL, Mclaughlin EA \& Nixon B 2015b The impact of oxidative stress on chaperone-mediated human spermegg interaction. Human Reproduction 30 2597-2613. (https://doi. org/10.1093/humrep/dev214)

Brown PR, Miki K, Harper DB \& Eddy EM 2003 A-kinase anchor protein 4 binding proteins in the fibrous sheath of the sperm flagellum. Biology of Reproduction 68 2241-2248. (https://doi.org/10.1095/ biolreprod.102.013466)

Carbone DJ, Jr, Seifarth K, Thomas AJ, Jr \& Agarwal A 1997 Improved motile sperm recovery by a hyperosmotic Percoll gradient. Journal of Assisted Reproduction and Genetics 14 394-397. (https://doi. org/10.1007/BF02766147)

Carmona E, Weerachatyanukul W, Soboloff T, Fluharty AL, White D, Promdee L, Ekker M, Berger T, Buhr M \& Tanphaichitr N 2002 Arylsulfatase $\mathrm{A}$ is present on the pig sperm surface and is involved in sperm-zona pellucida binding. Developmental Biology 247 182-196. (https://doi.org/10.1006/dbio.2002.0690)

Carrera A, Gerton GL \& Moss SB 1994 The major fibrous sheath polypeptide of mouse sperm: structural and functional similarities to the A-kinase anchoring proteins. Developmental Biology 165 272-284. (https://doi.org/10.1006/dbio.1994.1252)

Colenbrander B, Feitsma H \& Grooten HJ 1993 Optimizing semen production for artificial insemination in swine. Journal of Reproduction and Fertility: Supplement 48 207-215.

Colenbrander B, Gadella BM \& Stout TA 2003 The predictive value of semen analysis in the evaluation of stallion fertility. Reproduction in Domestic Animals 38 305-311. (https://doi.org/10.1046/j.14390531.2003.00451.x)

Colledge M \& Scott JD 1999 AKAPs: from structure to function. Trends in Cell Biology 9 216-221. (https://doi.org/10.1016/s0962-8924(99)01558-5)

Cui Z, Sharma R \& Agarwal A 2016 Proteomic analysis of mature and immature ejaculated spermatozoa from fertile men. Asian Journal of Andrology 18 735-746. (https://doi.org/10.4103/1008-682X.164924)

Dalleau S, Baradat M, Guéraud F \& Huc L 2013 Cell death and diseases related to oxidative stress: 4-hydroxynonenal (HNE) in the balance. Cell Death and Differentiation 20 1615-1630. (https://doi.org/10.1038/ cdd.2013.138)

de Mateo S, Martinez-Heredia J, Estanyol JM, Dominguez-Fandos D, VidalTaboada JM, Ballesca JL \& Oliva R 2007 Marked correlations in protein expression identified by proteomic analysis of human spermatozoa. Proteomics 7 4264-4277. (https://doi.org/10.1002/pmic.200700521)

Delehedde M, Bloomaert D, Jouy N, Scabello J, Miersman H, Franck T, Serteyn D, Mitchell V \& Sergeant N 2018 Concentration of proAKAP4 as a pertinent read-out of sperm quality in mammals. Animal Reproduction Science 194 24. (https://doi.org/10.1016/j.anireprosci.2018.04.053)

Delehedde M, Carracedo S, Selleslagh M, Amirat-Briand L \& Sergeant N 2019 ProAKAP4 polypeptide as a biomarker of sperm functionality and male fertility disorders. International Journal of Gynecology and Reproductive Sciences 2 13-19.

Doorn JA \& Petersen DR 2002 Covalent modification of amino acid nucleophiles by the lipid peroxidation products 4-hydroxy-2-nonenal and 4-oxo-2-nonenal. Chemical Research in Toxicology 15 1445-1450. (https://doi.org/10.1021/tx025590o)

Eddy EM, Toshimori K \& O'brien DA 2003 Fibrous sheath of mammalian spermatozoa. Microscopy Research and Technique 61 103-115. (https:// doi.org/10.1002/jemt.10320) 
Esterbauer H, Schaur RJ \& Zollner H 1991 Chemistry and biochemistry of 4-hydroxynonenal, malonaldehyde and related aldehydes. Free Radical Biology and Medicine 11 81-128. (https://doi.org/10.1016/08915849(91)90192-6)

Fanny J, Julien S, Francisco-Jose FG, Sabiha E, Sophie DD, Luc B, Hélène B, Nicolas S \& Valérie $\mathbf{M} 2018$ Gel electrophoresis of human sperm: a simple method for evaluating sperm protein quality. Basic and Clinical Andrology 28 10-10. (https://doi.org/10.1186/s12610-0180076-0)

Frapsauce C, Pionneau C, Bouley J, Delarouziere V, Berthaut I, Ravel C, Antoine JM, Soubrier F \& Mandelbaum J 2014 Proteomic identification of target proteins in normal but nonfertilizing sperm. Fertility and Sterility 102 372-380. (https://doi.org/10.1016/j.fertnstert.2014.04.039)

Gibb Z, Lambourne SR \& Aitken RJ 2014 The paradoxical relationship between stallion fertility and oxidative stress. Biology of Reproduction 91 77. (https://doi.org/10.1095/biolreprod.114.118539)

Gibb Z, Lambourne SR, Curry BJ, Hall SE \& Aitken RJ 2016 Aldehyde dehydrogenase plays a pivotal role in the maintenance of stallion sperm motility. Biology of Reproduction 94 133. (https://doi.org/10.1095/ biolreprod.116.140509)

Guerin JF, Mathieu C, Lornage J, Pinatel MC \& Boulieu D 1989 Improvement of survival and fertilizing capacity of human spermatozoa in an IVF programme by selection on discontinuous Percoll gradients. Human Reproduction 4 798-804. (https://doi.org/10.1093/oxfordjournals. humrep.a136989)

Hall SE, Aitken RJ, Nixon B, Smith ND \& Gibb Z 2017 Electrophilic aldehyde products of lipid peroxidation selectively adduct to heat shock protein 90 and arylsulfatase A in stallion spermatozoa. Biology of Reproduction 96 107-121. (https://doi.org/10.1095/biolreprod.116.145292)

Intasqui P, Camargo M, Del Giudice PT, Spaine DM, Carvalho VM, Cardozo KHM, Cedenho AP \& Bertolla RP 2013 Unraveling the sperm proteome and post-genomic pathways associated with sperm nuclear DNA fragmentation. Journal of Assisted Reproduction and Genetics 30 1187-1202. (https://doi.org/10.1007/s10815-013-0054-6)

Jiménez I, Fierro R, González-Márquez H, Mendoza-Hernández G, Romo S \& Betancourt M 2006 Carbohydrate affinity chromatography indicates that arylsulfatase-A from capacitated boar sperm has mannose and N-acetylglucosamine/sialic acid residues. Archives of Andrology 52 455-462. (https://doi.org/10.1080/01485010600694690)

Karamahmutoglu H, Erdem A, Erdem M, Mutlu MF, Bozkurt N, Oktem M, Ercan DD \& Gumuslu S 2014 The gradient technique improves success rates in intrauterine insemination cycles of unexplained subfertile couples when compared to swim up technique; a prospective randomized study. Journal of Assisted Reproduction and Genetics 31 1139-1145. (https:// doi.org/10.1007/s10815-014-0274-4)

Krisfalusi M, Miki K, Magyar PL \& O'brien DA 2006 Multiple glycolytic enzymes are tightly bound to the fibrous sheath of mouse spermatozoa. Biology of Reproduction 75 270-278. (https://doi.org/10.1095/ biolreprod.105.049684)

Kwon WS, Oh SA, Kim YJ, Rahman MS, Park YJ \& Pang MG 2015a Proteomic approaches for profiling negative fertility markers in inferior boar spermatozoa. Scientific Reports 5 13821. (https://doi.org/10.1038/ srep13821)

Kwon WS, Rahman MS, Lee JS, Yoon SJ, Park YJ \& Pang MG 2015b Discovery of predictive biomarkers for litter size in boar spermatozoa. Molecular and Cellular Proteomics 14 1230-1240. (https://doi. org/10.1074/mcp.M114.045369)

Langeberg LK \& Scott JD 2015 Signalling scaffolds and local organization of cellular behaviour. Nature Reviews: Molecular Cell Biology 16 232-244. (https://doi.org/10.1038/nrm3966)

Le Couazer D, Delehedde M, Jouy N, Loyens A, Ruelle I, Sergeant N, Michaud S, Lamia BA \& Bencharif D 2019 ProAKAP4 as a valuable marker to assess sperm quality in dogs. Reproduction in Domestic Animals 54 91-99. (https://doi.org/10.1111/rda.13449)

Legare C, Akintayo A, Blondin P, Calvo E \& Sullivan R 2017 Impact of male fertility status on the transcriptome of the bovine epididymis. Molecular Human Reproduction 23 355-369. (https://doi.org/10.1093/molehr/ gax019)

Lord T, Martin JH \& Aitken RJ 2015 Accumulation of electrophilic aldehydes during postovulatory aging of mouse oocytes causes reduced fertility, oxidative stress, and apoptosis. Biology of Reproduction 9233. (https://doi.org/10.1095/biolreprod.114.122820)
Luconi M, Cantini G, Baldi E \& Forti G 2011 Role of a-kinase anchoring proteins (AKAPs) in reproduction. Frontiers in Bioscience 16 1315-1330. (https://doi.org/10.2741/3791)

Martín-Cano FE, Gaitskell-Phillips G, Ortiz-Rodríguez JM, SilvaRodríguez A, Román Á, Rojo-Domínguez P, Alonso-Rodríguez E, Tapia JA, Gil MC, Ortega-Ferrusola C et al. 2020 Proteomic profiling of stallion spermatozoa suggests changes in sperm metabolism and compromised redox regulation after cryopreservation. Journal of Proteomics 221 103765. (https://doi.org/10.1016/j.jprot.2020.103765)

Mayer MP \& Bukau B 2005 Hsp70 chaperones: cellular functions and molecular mechanism. Cellular and Molecular Life Sciences $\mathbf{6 2}$ 670-684. (https://doi.org/10.1007/s00018-004-4464-6)

Mihalas BP, De Iuliis GN, Redgrove KA, Mclaughlin EA \& Nixon B 2017 The lipid peroxidation product 4-hydroxynonenal contributes to oxidative stress-mediated deterioration of the ageing oocyte. Scientific Reports 7 6247. (https://doi.org/10.1038/s41598-017-06372-z)

Miki K, Willis WD, Brown PR, Goulding EH, Fulcher KD \& Eddy EM 2002 Targeted disruption of the Akap4 gene causes defects in sperm flagellum and motility. Developmental Biology 248 331-342. (https:// doi.org/10.1006/dbio.2002.0728)

Mitchell LA, De Iuliis GN \& Aitken RJ 2011 The TUNEL assay consistently underestimates DNA damage in human spermatozoa and is influenced by DNA compaction and cell vitality: development of an improved methodology. International Journal of Andrology $342-13$. (https://doi. org/10.1111/j.1365-2605.2009.01042.x)

Moazamian R, Polhemus A, Connaughton H, Fraser B, Whiting S, Gharagozloo P \& Aitken RJ 2015 Oxidative stress and human spermatozoa: diagnostic and functional significance of aldehydes generated as a result of lipid peroxidation. Molecular Human Reproduction 21 502-515. (https://doi.org/10.1093/molehr/gav014)

Morrell JM, Johannisson A \& Rodriguez-Martinez H 2011 Effect of osmolarity and density of colloid formulations on the outcome of SLC-selection of stallion spermatozoa. ISRN Veterinary Science $\mathbf{2 0 1 1}$ 128984. (https://doi.org/10.5402/2011/128984)

Morris LHA \& Allen WR 2002 Reproductive efficiency of intensively managed Thoroughbred mares in Newmarket. Equine Veterinary Journal 34 51-60. (https://doi.org/10.2746/042516402776181222)

Moss SB, Turner RMO, Burkert KL, Vanscoy Butt H \& Gerton GL 1999 Conservation and function of a bovine sperm A-kinase anchor protein homologous to mouse AKAP82. Biology of Reproduction 61 335-342. (https://doi.org/10.1095/biolreprod61.2.335)

Nath LC, Anderson GA \& Mckinnon AO 2010 Reproductive efficiency of Thoroughbred and Standardbred horses in north-east Victoria. Australian Veterinary Journal 88 169-175. (https://doi.org/10.1111/j.17510813.2010.00565.x)

Netherton JK, Hetherington L, Ogle RA, Velkov T \& Baker MA 2017 Proteomics analysis of good and poor quality human sperm demonstrates several proteins are routinely aberrantly regulated. Biology of Reproduction 99 395-408. (https://doi.org/10.1093/biolre/iox166)

Netzel-Arnett S, Bugge TH, Hess RA, Carnes K, Stringer BW, Scarman AL, Hooper JD, Tonks ID, Kay GF \& Antalis TM 2009 The glycosylphosphatidylinositol-anchored serine protease PRSS21 (testisin) imparts murine epididymal sperm cell maturation and fertilizing ability. Biology of Reproduction 81 921-932. (https://doi.org/10.1095/ biolreprod.109.076273)

Nixon B, Bernstein IR, Cafe SL, Delehedde M, Sergeant N, Anderson AL, Trigg NA, Eamens AL, Lord T, Dun MD et al. 2019a A-kinase anchor protein 4 is vulnerable to oxidative adduction in male germ cells. Frontiers in Cell and Developmental Biology 7 319. (https://doi. org/10.3389/fcell.2019.00319)

Nixon B, Johnston SD, Skerrett-Byrne DA, Anderson AL, Stanger SJ, Bromfield EG, Martin JH, Hansbro PM \& Dun MD 2019b Modification of crocodile spermatozoa refutes the tenet that post-testicular sperm maturation is restricted to mammals. Molecular and Cellular Proteomics 18 S59-S76. (https://doi.org/10.1074/mcp.RA118.000904)

Novak S, Smith TA, Paradis F, Burwash L, Dyck MK, Foxcroft GR \& Dixon WT 2010 Biomarkers of in vivo fertility in sperm and seminal plasma of fertile stallions. Theriogenology 74 956-967. (https://doi. org/10.1016/j.theriogenology.2010.04.025)

Pagan JD, Koch A \& Caddel SE 2005 Size matters at the sales. In Advances in Equine Nutrition III, pp. 433-437. Ed JD Pagan. Nottingham, UK: Nottingham University Press. 
Park YJ, Kwon WS, Oh SA \& Pang MG 2012 Fertility-related proteomic profiling bull spermatozoa separated by Percoll. Journal of Proteome Research 11 4162-4168. (https://doi.org/10.1021/pr300248s)

Parlevliet JM \& Colenbrander B 1999 Prediction of first season stallion fertility of 3-year-old Dutch Warmbloods with prebreeding assessment of percentage of morphologically normal live sperm. Equine Veterinary Journal 31 248-251. (https://doi.org/10.1111/j.2042-3306.1999. tb03181.x)

Peddinti D, Nanduri B, Kaya A, Feugang JM, Burgess SC \& Memili E 2008 Comprehensive proteomic analysis of bovine spermatozoa of varying fertility rates and identification of biomarkers associated with fertility. BMC Systems Biology 2 19. (https://doi.org/10.1186/1752-0509-2-19)

Petrunkina AM, Waberski D, Gunzel-Apel AR \& Topfer-Petersen E 2007 Determinants of sperm quality and fertility in domestic species. Reproduction 134 3-17. (https://doi.org/10.1530/REP-07-0046)

Polakis PG \& Wilson JE 1985 An intact hydrophobic N-terminal sequence is critical for binding of rat brain hexokinase to mitochondria. Archives of Biochemistry and Biophysics 236 328-337. (https://doi. org/10.1016/0003-9861(85)90633-2)

Punjabi U, Gerris J, Van Bijlen J, Delbeke L, Gielis M \& Buytaert P 1990 Comparison between different pre-treatment techniques for sperm recovery prior to intrauterine insemination, GIFT or IVF. Human Reproduction 5 75-83. (https://doi.org/10.1093/oxfordjournals.humrep. a137046)

Rahamim Ben-Navi L, Almog T, Yao Z, Seger R \& Naor Z 2016 A-kinase anchoring protein 4 (AKAP4) is an ERK1/2 substrate and a switch molecule between CAMP/PKA and PKC/ERK1/2 in human spermatozoa. Scientific Reports 6 37922-37922. (https://doi.org/10.1038/srep37922)

Redgrove KA, Anderson AL, Mclaughlin EA, O'bryan MK, Aitken RJ \& Nixon B 2012a Investigation of the mechanisms by which the molecular chaperone HSPA2 regulates the expression of sperm surface receptors involved in human sperm-oocyte recognition. Molecular Human Reproduction 19 120-135. (https://doi.org/10.1093/molehr/gas064)

Redgrove KA, Nixon B, Baker MA, Hetherington L, Baker G, Liu DY \& Aitken RJ 2012b The molecular chaperone HSPA2 plays a key role in regulating the expression of sperm surface receptors that mediate spermegg recognition. PLOS ONE 7 e50851. (https://doi.org/10.1371/journal. pone.0050851)

Ruelle I, Charreaux F, Bencharif D, Thorin C, Michaud S, Schmitt E, Sergeant N, Briand-Amirat L \& Delehedde M 2019 Assessment of the sperm specific protein proAKAP4 as a marker to evaluate sperm quality and fertility in Holstein bulls. Revista Brasileira de Reprodução Animal 43472.

Sergeant N, Jumeau F, Eddarkaoui S, Sigala J, Dossou GF, Delehedde M, Buee L, Yvoz JF \& Mitchell V 2016 Investigating proteomic methods and tools to assess sperm quality. Animal Reproduction Science 169 125-126. (https://doi.org/10.1016/j.anireprosci.2016.03.072)

Sergeant N, Briand-Amirat L, Bencharif D \& Delehedde M 2019 The sperm specific protein proAKAP4 as an innovative marker to evaluate sperm quality and fertility. Journal of Dairy and Veterinary Sciences 11 1-6. (https://doi.org/10.19080/JDVS.2019.11.555803)

Shalika S, Dugan K, Pelesh D \& Padilla S 1995 A mono-Percoll separation technique improves sperm recovery of normal and male factor specimens when compared with the swim-up technique. Human Reproduction 10 3195-3197. (https://doi.org/10.1093/oxfordjournals.humrep.a135886)

Shao X, Xue J \& van der Hoorn F A 2001 Testicular protein Spag5 has similarity to mitotic spindle protein Deepest and binds outer dense fiber protein Odf1. Molecular Reproduction and Development 59 410-416. (https://doi.org/10.1002/mrd.1047)

Sharma RK \& Agarwal A 1996 Sperm quality improvement in cryopreserved human semen. Journal of Urology 156 1008-1012. (https://doi. org/10.1016/S0022-5347(01)65687-8)
Sieme H 2009 Semen evaluation. In Equine Breeding Management and Artificial Insemination, 2nd ed. Ed JC Samper. St. Louis, MO: Saunders Elselvier.

Singh R, Junghare V, Hazra S, Singh U, Sengar GS, Raja TV, Kumar S, Tyagi S, Das AK, Kumar A et al. 2019 Database on spermatozoa transcriptogram of catagorised Frieswal crossbred (Holstein Friesian X Sahiwal) bulls. Theriogenology 129 130-145. (https://doi.org/10.1016/j. theriogenology.2019.01.025)

Somashekar L, Selvaraju S, Parthipan S \& Ravindra JP 2015 Profiling of sperm proteins and association of sperm PDC-109 with bull fertility. Systems Biology in Reproductive Medicine 61 376-387. (https://doi.org/ 10.3109/19396368.2015.1094837)

Somashekar L, Selvaraju S, Parthipan S, Patil SK, Binsila BK, Venkataswamy MM, Karthik Bhat S \& Ravindra JP 2017 Comparative sperm protein profiling in bulls differing in fertility and identification of phosphatidylethanolamine-binding protein 4, a potential fertility marker. Andrology 5 1032-1051. (https://doi.org/10.1111/andr.12404)

Sun L, Shukair S, Naik TJ, Moazed F \& Ardehali H 2008 Glucose phosphorylation and mitochondrial binding are required for the protective effects of hexokinases I and II. Molecular and Cellular Biology 28 1007-1017. (https://doi.org/10.1128/MCB.00224-07)

Swegen A, Curry BJ, Gibb Z, Lambourne SR, Smith ND \& Aitken RJ 2015 Investigation of the stallion sperm proteome by mass spectrometry. Reproduction 149 235-244. (https://doi.org/10.1530/REP-14-0500)

Swegen A, Smith ND, Gibb Z, Curry BJ \&Aitken RJ 2019 The serine protease testisin is present on the surface of capacitated stallion spermatozoa and interacts with key zona pellucida binding proteins. Andrology 7 199-212. (https://doi.org/10.1111/andr.12569)

Takahashi T 2015 The effect of age on the racing speed of Thoroughbred racehorses. Journal of Equine Science 26 43-48. (https://doi.org/10.1294/ jes.26.43)

Tyanova S, Temu T, Sinitcyn P, Carlson A, Hein MY, Geiger T, Mann M \& Cox J 2016 The Perseus computational platform for comprehensive analysis of (prote)omics data. Nature Methods 13 731-740. (https://doi. org/10.1038/nmeth.3901)

Welch EJ, Jones BW \& Scott JD 2010 Networking with AKAPs: contextdependent regulation of anchored enzymes. Molecular Interventions $\mathbf{1 0}$ 86-97. (https://doi.org/10.1124/mi.10.2.6)

Wessel D \& Flügge UI 1984 A method for the quantitative recovery of protein in dilute solution in the presence of detergents and lipids. Analytical Biochemistry 138 141-143. (https://doi.org/10.1016/00032697(84)90782-6)

Wilson JE 2003 Isozymes of mammalian hexokinase: structure, subcellular localization and metabolic function. Journal of Experimental Biology 206 2049-2057. (https://doi.org/10.1242/jeb.00241)

Xavier MJ, Nixon B, Roman SD \& Aitken RJ 2018 Improved methods of DNA extraction from human spermatozoa that mitigate experimentallyinduced oxidative DNA damage. PLoS ONE 13 e0195003. (https://doi. org/10.1371/journal.pone.0195003)

Xu W, Hu H, Wang Z, Chen X, Yang F, Zhu Z, Fang P, Dai J, Wang L, Shi $\mathbf{H}$ et al. 2012 Proteomic characteristics of spermatozoa in normozoospermic patients with infertility. Journal of Proteomics 75 5426-5436. (https://doi.org/10.1016/j.jprot.2012.06.021)

Received 23 May 2020

First decision 29 June 2020

Revised manuscript received 27 July 2020

Accepted 17 August 2020 